catabolism of triglyceride rich lipoprotein. Several studies have reported associations between serum lipid (TG, HDL) levels and restriction fragment length polymorphisms (RFLPs) of the LPL gene (Pvu II and Hind III).

The aim of the present study was to assess the effect of genetic variations at the lipoprotein lipase (LPL) gene locus on lipid-related variables in obese subjects, before and after a hypocaloric diet.

Unrelated obese subjects ( 80 women and 40 men) were recruited on the basis of $120 \%$ of ideal weight as determined by Metropolitan Life Insurance tables of 1959. The mean ( \pm SD) age of the subjects was $42 \pm 10$ years and the mean ( \pm SD) body mass index (BMI) was $33.2 \pm 5.4 \mathrm{~kg} / \mathrm{m}^{2}$. They were submitted to a restrictive diet (1 $824 \pm$ $311 \mathrm{kcal} / \mathrm{d}$ ), containing $42 \%$ of energy as fat, $19.4 \%$ as protein and $37 \%$ as carbohydrates, during 3 months. Diabetic patients or patients using drugs known to modify lipid levels were excluded. All subjects were French Caucasians.

Two restriction length polymorphisms (RFLPs) (Pvu II and Hind III) were determined by enzymatic digestion of DNA after PCR amplification. Digestion with Hind III generated 2 alleles, $\mathrm{H} 1$ and $\mathrm{H}_{2}$, with frequencies of 0.28 and 0.72 , respectively. Digestion with $\mathrm{Pvu}$ II generated 2 alleles, $\mathrm{P} 1$ and $\mathrm{P} 2$, with frequencies of 0.49 and 0.51 , respectively.

On spontaneous diet, subjects with $\mathrm{H}_{2} \mathrm{H}_{2}$ genotypes had significantly higher TG in serum and VLDL $(P<0.005)$ than $\mathrm{H} 1$ subjects. After a hypocaloric diet, subjects with $\mathrm{H} 2 \mathrm{H} 2$ genotypes reduced their total and VLDL-TG more than subjects with $\mathrm{H} 1$ allele.

According to Pvu II genotypes, there was no difference between lipid-related variables in obese subjects, either on a spontaneous diet or after the hypocaloric diet.

In conclusion, the lipoprotein profile is not the same for all obese people and depends on genetic factors, at least in part. The lipid response to hypocaloric diet also depends on genetic factors, which means that the benefits of such diets are not identical for all obese people.

\section{Protein metabolism}

Increased ATP-ubiquitin-dependent proteolysis in skeletal muscles proximal to the tumor of Yoshida-sarcoma-bearing rats. S Temparis ${ }^{1}, M$ Asensi ${ }^{2}$, D Taillandier 1, D Larbaud ${ }^{1}$, E Aurousseau 1 , A Obled ${ }^{1}$, D Béchet 1, M Ferrara 1, JM Estrela 2, D Attaix ${ }^{1}$ (1 INRA-Theix, Centre de Recherche en Nutrition Humaine et Unité d'Étude du Métabolisme Azoté, 63122, Saint-Genès-Champanelle, France; 2 Universidad de Valencia, 46010 Valencia, Spain)

Skeletal muscle protein wasting is commonly observed in cancer patients and tumor-bearing animals, and results from impaired protein synthesis and/or enhanced proteolysis [Pisters and Brennan (1990) Annu Rev Nutr 10, 107-132]. Experiments were carried out to demonstrate whether there is proximal effect of a tumor on skeletal muscle proteolysis, and a coordinate activation of the 3 major proteolytic systems of skeletal muscle (ie lysosomal, $\mathrm{Ca}^{2+-}$ and ATP-ubiquitin-dependent) in rats bearing a small $(<0.5 \%$ body weight) and nonmetastasic tumor.

Young male Wistar rats with an initial body weight of $50 \mathrm{~g}$ were randomly divided into 2 groups of 7 control and tumor-bearing animals. The tumor group received an injection of $60 \mathrm{mg}$ of sarcoma homogenate in $0.3 \mathrm{ml}$ saline into the left vastus lateralis muscle. Animals were sacrificed $5 \mathrm{~d}$ after tumor implantation. The rates of total protein synthesis and breakdown were measured in incubated extensor digitorum longus (EDL) muscles as described by Tischler et al [(1982) J Biol Chem 257, 1613-1621]. Proteolysis was also measured in the presence of inhibitors of lysosomal and $\mathrm{Ca}^{2+-d e p e n d e n t ~ p r o-~}$ teases [Wing and Goldberg (1993) Am J Physiol 264, E668-676]. Tibialis anterior (TA) muscles were also excised for measuring the expression of proteolytic systems, using Northern blot procedures.

The protein masses of both EDL and TA muscles of the tumor-bearing leg were significantly reduced $5 \mathrm{~d}$ after tumor implantation $(P<0.01)$ compared to the other (control) leg. The rate of total protein breakdown was $30-40 \%$ higher $(P<$ 0.01 ) in the EDL muscle from the tumor-bearing leg, compared with the control leg, but protein synthesis was unchanged. Neither saline nor heat-inactivated tumor cells injections resulted in muscle atrophy or increased proteolysis in the EDL muscle $5 \mathrm{~d}$ after treatments. Incubating EDL 
muscles from tumor-bearing rats in the presence of inhibitors of the lysosomal and the $\mathrm{Ca}^{2+}$-dependent proteolytic pathways did not reduce differences between rates of proteolysis in EDL muscles from the tumor-bearing and the control legs. mRNA levels for cathepsin $B$ were similar in the TA muscles of the tumor-bearing and control legs, but higher mRNA levels for m-calpain were observed in muscles of the tumor-bearing leg. By contrast, when EDL muscies from tumor-bearing rats were incubated under ATP-depleting conditions, proteolysis was almost identical in the tumor-bearing and control legs. In addition, mRNA levels for ubiquitin, $14 \mathrm{kDa}$ ubiquitin carrier protein $\mathrm{E} 2$ and $\mathrm{C} 8$ or $\mathrm{C} 9$ proteasome subunits markedly increased in the TA muscle of the tumor-bearing leg compared with the control-limb. By contrast, all the parameters measured in the control-limb of tumor-bearing rats were identical to those observed in control rats.

This study suggests that the Yoshida sarcoma stimulates proximaily protein breakdown in skeletal muscle at an early stage of tumor development. This activation presumably involves the ATP-ubiquitin-dependent proteolytic pathway, and possibly the $\mathrm{Ca}^{2+}$-dependent proteinases.

\section{Effects of age and divergent selection for body weight on muscle protein turn- over in chickens. S Tesseraud, JC Cam- mas, AM Chagneau (INRA, Station de}

Recherches Avicoles, 37380 Nouzilly, France)

Rates of muscle protein turnover were determined at 2 and 4 weeks of age in 2 lines of chickens selected from the Bresse-pile strain for high or low growth rate (HG and LG) by Ricard [(1975) Ann Genet Sel Anim 7, 427-443]. Protein fractional synthesis rates (Ks) in the Pectoralis major muscle were measured in vivo according to the flooding dose method [Garlick et al (1980) Biochem J192, 719-723]. Ten min before slaughter, the 3-h-fasted animals received a single intravenous injection of unlabelled $L$-phenylalanine $(150 \mu \mathrm{mol} / 100 \mathrm{~g})$ combined with $1.85 \mathrm{MBq} / 100 \mathrm{~g}$ of $\mathrm{L}-\left[4-{ }^{3} \mathrm{H}\right]$ phenylalanine (Amersham, 0.96 $\mathrm{TBq} / \mathrm{mmol}$ ) to flood the precursor pools. Rates of protein breakdown $(\mathrm{Kd})$ were estimated as the difference between the synthesis rates and the growth rates of muscle protein.

In 4-week-old chickens the fractional rates of protein synthesis were $60 \%$ of their values at 2 weeks of age for both lines (table I). This developmental decline, also observed in whole body for growing chickens [Muramatsu and Okumura (1985) J Nutr 115, 483-490], was related to decreased capacities for protein synthesis (Cs), ie RNA/protein ratio, whereas the ribosomal activity, ie the RNA activity or the translational efficiency kRNA, was constant ( 2 weeks: $11.9 \pm 0.5$ and $12.3 \pm 0.6 \mathrm{mg} /(\mathrm{mg} \cdot \mathrm{d})$ in $\mathrm{HG}$ and $\mathrm{LG}$ lines respectively; 4 weeks: $11.6 \pm 0.8$ and $12.1 \pm 0.8$ $\mathrm{mg} /(\mathrm{mg} \cdot \mathrm{d})$ respectively).

Table I. Effects of divergent selection for body weight on protein turnover in the pectoralis major muscle of 2 and 4-wk-old chickens (S Tesseraud et al).

\begin{tabular}{|c|c|c|c|c|c|c|c|}
\hline \multirow{2}{*}{$\begin{array}{l}\text { Age } \\
\text { (weeks) }\end{array}$} & \multirow[t]{2}{*}{ Line $^{\prime}$} & \multirow[t]{2}{*}{$n$} & \multicolumn{2}{|c|}{ Fractional rates (\%/day) } & \multirow{2}{*}{$\begin{array}{c}C s^{2} \\
(\mu g / m g)\end{array}$} & \multicolumn{2}{|c|}{ Absolute amounts $(\mathrm{mg} / \mathrm{d})$} \\
\hline & & & Ks & $K d$ & & Synthesis & Degradation \\
\hline 2 & $\begin{array}{l}\mathrm{HG} \\
\mathrm{LG}\end{array}$ & $\begin{array}{r}10 \\
7\end{array}$ & $\begin{array}{l}16.6^{a} \\
18.8^{a}\end{array}$ & $\begin{array}{l}2.1^{a} \\
4.3^{b}\end{array}$ & $\begin{array}{l}13.9^{a} \\
15.2^{a}\end{array}$ & $\begin{array}{r}157.2^{\mathrm{a}} \\
71.2^{\mathrm{b}}\end{array}$ & $\begin{array}{l}22.2^{\mathrm{a}} \\
16.8^{\mathrm{a}}\end{array}$ \\
\hline 4 & $\begin{array}{lr}\text { HG } & 1 \\
\text { LG } & 1 \\
\text { Pooled } & \text { S }\end{array}$ & $\begin{array}{l}10 \\
11 \\
\text { SE }\end{array}$ & $\begin{array}{c}10.6^{\mathrm{b}} \\
11.1^{\mathrm{b}} \\
0.9^{\mathrm{n}}\end{array}$ & $\begin{array}{l}5.8^{b} \\
4.3^{b} \\
0.7^{3}\end{array}$ & $\begin{array}{l}9.2^{b} \\
9.1^{b} \\
0.4\end{array}$ & $\begin{array}{c}278.3^{c} \\
117.3^{d} \\
10.3\end{array}$ & $\begin{array}{c}152.8^{b} \\
46.2^{a} \\
9.6\end{array}$ \\
\hline
\end{tabular}

Means for $7-11$ chickens. Values not sharing a common subscripts were significantly different $(p<0.05) .1$ Lines of chickens selected for high or low growth rates (HG and LG). ${ }^{2}$ Ribosomal capacity. 